\title{
GROUPING STUDENTS ACCORDING TO MODALITIES OF COMPETENCE (SELF)ASSESSMENT AND EDUCATION PLANNING
}

\section{Lepa Babić ${ }^{1}$}

Ministry of Foreign Affairs - Bosnia and Herzegovina

\begin{abstract}
:
The students at the end of their study find themselves on the transition from the role of a student with an emphasis on learning to the role of an employee with an emphasis on work performance. A survey was conducted on a sample of students from Skopje $(\mathrm{N}=189$ ) with the aim to determine typical student groups according to modalities of (self)assessment of key competencies and education planning. The instruments used were composed for this research: questionnaire for self-assessment of key competences acquired during study (Cronbach's Alpha = 0.933), questionnaire for assessment of employers' requirements for key competences (0.938), questionnaire of beliefs about additional education (0.861), questionnaire of selection of additional education (0.919). Based on discriminatory and clustering analysis, five groups are distinguished in the space defined by vectors of research variables (the coefficient of canonical correlation are $.85, .73, .66, .45)$. Differences between five groups are in intensity, but also in quality (Box's M test $F=1.479$, Sig. $<.001$ ). The mutual distance on linear composite that maximally differentiate groups is 4.5 standard deviations for the first function, 3.5 for the second, 2.5 for the third, and 1.5 for the fourth. We gave the following names to the groups of students: High Careerism (39\% of the sample), Low Careerism (14.5\%), Narrow Professionalism (14.5\%), Pragmatic Careerism (16.5\%), and Self-Confident Careerism (15,5\%). Therefore, $70 \%$ of students are keenly considering the role of additional education in raising competencies, which speaks of a clear commitment to developing professionalism and improving competencies through learning and education. On the other hand, 30\% of students show a tendency to negatively monitor additional education in the context of competence development. In order to better understand results obtained future research should explore which motives, apart from education and learning, participate in the need for studying.
\end{abstract}

Keywords: key competences, additional education, professionalism, career

${ }^{1}$ lepababic@yahoo.com 


\section{Introduction}

A specific period in the development of a young man is the transition from study to work. One prepares for the period of labour during childhood and adolescence. Early career experiences gradually develop career concepts, such as career maturity (Patton, Creed, \& Muller, 2002), certainty in making career decisions (Creed, Prideaux, \& Patton, 2005), job aspirations and work values (Porfeli, 2007) and many others (Mortimer \& Zimmer-Gembeck, 2007; Staff, Messersmith, \& Schulenberg, 2009; Zimmer-Gembeck \& Mortimer, 2006). This development is accompanied by problems arising from lack of work experience and a number of factors related to the characteristics of adolescent and young adult developmental periods (Barnes, Bassot, \& Chant, 2011). This results in vague ideas about careers in young people.

People who have just graduated often feel unprepared to meet new forms of learning, new ways of living, and new circumstances of work (Olson, 2014). What is noticeable is that graduates lack core skills or key competencies to navigate the world of work (Banerji, 2007; Casner-Lotto \& Barrington, 2006), and these are precisely the skills that are associated with workplace identity transition issues (Hinchliffe, 2013). It turned out that students who often participated in activities that develop competencies for the 21st century, during the last year of study, had a higher quality of work at job, which included gaining a role in decision-making and greater workplace evaluation (Gallup Inc., 2013).

A particular paradox is present in the need for a degree of maturity in order to develop certain non-cognitive skills (Olson, 2014), and the fact that participating in extracurricular and similar activities helps both to gain maturity and acquire the necessary skills. Employers implicitly use the notion of workplace identity when evaluating job-seeking graduates, and extremely value the broadbased experience students can gain through volunteering, societies and events (Hinchliffe, 2013).

Successful career guidance has immediate outcomes expressed in enhancing knowledge and skills, enhancing the ability to implement successful transitions, boosting self-esteem and self-respect, enhancing motivation and willingness to consider new business or educational options (Hughes, Bosley, Bowes, \& Bysshe, 2002). Given that today an individual is expected to develop selfdirection and responsibility in managing one's care (Cappellen \& Janssens, 2008; Hall \& Moss, 1998), it is necessary for young people to raise awareness of the competences necessary for competitiveness in the labour market and to invest in developing coping skills in the social environment. Individuals' employability 
increases with the development of an appropriate set of competences (Teijeiro, Rungo, \& Freire, 2013). As technical skills are developed during work, graduates are expected to possess soft, transferable skills. In addition to education, key competences are acquired through experience, training or more informal means (García-Aracil and Van der Velden, 2008; Hartog, 2001; Rychen and Salganik, 2003). Even while studying, some students choose and complete additional training to master the required competencies and qualify for a good start in the job market after graduation.

We explored in our research how students in their final years of university prepare to enter the job market. We have linked three sets of variables: selfassessment of key competences (which competences I have), assessment of key competencies sought by employers (which competences are required), and selfassessment of additional education planning to enhance one's own competences (which trainings I need). Self-assessment of competence is an integral part of knowledge about oneself as a factor necessary for making a career decision (Babić \& Kordić, 2014). In this paper, we will present the results of cluster analysis that group students according to the stated research variables.

\section{Method}

The survey was conducted with questionnaires on a sample of final year students from the faculties in Skopje $(\mathrm{N}=189) .53 .2 \%$ of female students and $46.8 \%$ of male students participated in the survey. Of these, 65 are students in philosophy, 51 in agriculture, 52 in mechanical engineering and 21 in military academy. The average age is 21.95 years. The average study grade is 8.02 (from 6 to 10$)$.

Questionnaires were compiled especially for this research: self-assessment questionnaire of key competences acquired during study (SKC), questionnaire of assessment of key competences necessary for obtaining employment (AKC), questionnaire of beliefs about additional education (BAE), and questionnaire for selection of additional education (SAE). A six-point Likert scale was used. The reason for choosing the six-point scale lies in the desire to avoid neutral responses, because with an even number of answers respondents have to choose either the positive or negative side of the answer. In competency questionnaires, respondents respond with their answers whether they have (significantly, much, completely) or do not have (not at all, slightly, moderately) a certain competence developed, or to what extent these competences are necessary (significantly, much, completely) or not (not at all, slightly, moderately) to get a job. 
Analysis of the metric properties of questionnaires was conducted on a mixed sample of students from Belgrade and Skopje $(\mathrm{N}=521)$. The instruments showed good metric characteristics (Cronbach $\alpha$ consistently .933; .938; .861; .919). The first two questionnaires (SKC, AKC) contain 24 key competences selected from research conducted by Educational Testing Service (ETS), Princeton, New Jersey (Burrus, Jackson, Xi, \& Steinberg, 2013), which includes competencies from three of the world's leading competency surveys for 21st century: 21st Century Skills Assessment and Teaching (ATC21S), University of Melbourne, (Griffin \& Care, 2015); The 21st Century Learning Partnership (P21), Washington, DC (www. p21.org); The William and Flora Hewlett Foundation, Menlo Park, California, (Finegold \& Notabartolo, 2008). Factor analysis grouped key competencies into four factors: skills (analytical skills, interpersonal skills, ability to execute), capacity for change/learning, general literacy, digital literacy.

Factors of beliefs about additional education were extracted from the BAE questionnaire (30 items): advancement for a job, professionalism development, negative beliefs (about additional education), and career advancement. The advancement for a job is related to the belief that additional education is a way of improving employees, which contributes to a more efficient and better quality of work, it is valued when applying for a job, and personal investment in it is profitable. The professionalism development speaks of the needs and desires to advance personal knowledge and skills, to become a professional and expert in the field of one's interest, as well as the willingness to learn and share knowledge. Negative beliefs support the views that additional education is a missed investment and a waste of time. Career advancement speaks of the belief that additional education is a means of expanding social network, achieving career goals, finding a work, improving life satisfaction, and improving competencies.

The factors of selection of additional education were extracted from the SAE questionnaire (20 items): values, key skills, academic topics, professional skills. Values denote educations on human values and global humanistic engagement. Key skills denote educations on skills such as interpersonal, self-management, community life, cognitive, and also capacity for change and key themes of the $21^{\text {st }}$ century. Academic topics denote education on general academic subjects such as philosophy, art, history. Professional skills denote education on professional or vocational skills, administrative skills, information management skills, and foreign language skills.

Grouping of students was carried out by cluster analysis which included modalities of self-assessment of competences, assessment of competences, beliefs about additional education and selection of additional education, four 
modalities each which gives a total of 16 variables. Discriminant analysis was used to determine functions by which groups differ, how groups differ, and the magnitudes of that difference.

\section{Results}

Five groups were clearly distinguished in the space defined by the vectors of the research variables (see Table 1). Five groups of people were effectively discriminated by each individual research variable (see Table 2).

Table 1. Summary of Canonical Discriminant Functions

\begin{tabular}{ccccccccc}
\hline $\begin{array}{c}\text { Func- } \\
\text { tion }\end{array}$ & Eigenvalue & $\begin{array}{c}\text { \% of } \\
\text { Vari- } \\
\text { ance }\end{array}$ & $\begin{array}{c}\text { Cumula- } \\
\text { tive \% }\end{array}$ & $\begin{array}{c}\text { Canonical } \\
\text { Correla- } \\
\text { tion }\end{array}$ & $\begin{array}{c}\text { Wilks' } \\
\text { Lambda }\end{array}$ & $\begin{array}{c}\text { Chi- }^{-} \\
\text {square }\end{array}$ & df & Sig. \\
\hline 1 & 2.612 & 54.3 & 54.3 & .850 & .057 & 502.258 & 64 & .000 \\
2 & 1.149 & 23.9 & 78.2 & .731 & .206 & 276.860 & 45 & .000 \\
3 & .789 & 16.4 & 94.6 & .664 & .444 & 142.567 & 28 & .000 \\
4 & .260 & 5.4 & 100.0 & .454 & .794 & 40.525 & 13 & .000 \\
\hline
\end{tabular}

Table 2. Tests of Equality of Group Means

\begin{tabular}{lccccc}
\hline & $\begin{array}{c}\text { Wilks' } \\
\text { Lambda }\end{array}$ & $\mathrm{F}$ & $\mathrm{df1}$ & $\mathrm{df2}$ & Sig. \\
\hline Advancement for a job & .703 & 19.209 & 4 & 182 & .000 \\
Professionalism development & .652 & 24.280 & 4 & 182 & .000 \\
Negative beliefs & .776 & 13.114 & 4 & 182 & .000 \\
Career advancement & .750 & 15.145 & 4 & 182 & .000 \\
Values & .601 & 30.268 & 4 & 182 & .000 \\
Key skills & .583 & 32.555 & 4 & 182 & .000 \\
Academic topics & .686 & 20.849 & 4 & 182 & .000 \\
Professional skills & .666 & 22.852 & 4 & 182 & .000 \\
SKC skills & .541 & 38.533 & 4 & 182 & .000 \\
SKC general literacy & .612 & 28.835 & 4 & 182 & .000 \\
SKC digital literacy & .514 & 43.107 & 4 & 182 & .000 \\
SKC capacity for change & .604 & 29.780 & 4 & 182 & .000 \\
AKC skills & .644 & 25.181 & 4 & 182 & .000 \\
AKC general literacy & .671 & 22.302 & 4 & 182 & .000 \\
AKC digital literacy & .608 & 29.326 & 4 & 182 & .000 \\
AKC capacity for change & .631 & 26.596 & 4 & 182 & .000 \\
\hline
\end{tabular}

The differences between the five groups are not only differences in intensity but also in quality (see Table 3). 
Table 3. Box's Test of Equality of Covariance Matrices

\begin{tabular}{cccccc}
\hline Ward Method & Rank & $\begin{array}{c}\text { Log Deter- } \\
\text { minant }\end{array}$ & Box's M & & 1042.908 \\
\hline 1 & 16 & -20.229 & F & Approx. & 1.479 \\
2 & 16 & -16.780 & & df1 & 544 \\
3 & 16 & -15.135 & & df2 & 31682.000 \\
4 & 16 & -20.027 & & Sig. & .000 \\
$\begin{array}{c}\text { Pooled within- } \\
\text { groups }\end{array}$ & 16 & -19.000 & & & \\
\hline
\end{tabular}

The first function distinguishes groups according to self-assessment and assessment of key competencies and professionalism. Of the competence (self) assessment variables only the assessment of Capacity for Change was not included. Other variables include beliefs related to the Professionalism Development and the choice of additional educations related to Professional Skills (see Table 4). So this function is an indicator of professionalism and competence. The second function distinguishes groups by the selection of educations from the Academic Topics and Values. The third function distinguishes groups by the selection of educations from the Key Skills, assessment of Capacity for Change, and beliefs related to Advancement for a Job and Career Advancement. This means that the third function is about people who want to change in the direction of developing key skills to improve their chances of a successful career and advancement of the job. The fourth function consists of Negative Beliefs about additional education. 
Table 4. Structure Matrix

\begin{tabular}{lcccc}
\hline & \multicolumn{4}{c}{ Function } \\
& 1 & 2 & 3 & 4 \\
\hline SKC skills & $.552^{*}$ & .039 & -.223 & .183 \\
SKC digital literacy & $.543^{*}$ & .004 & -.470 & -.118 \\
SKC capacity for change & $.481^{*}$ & .129 & -.148 & .226 \\
AKC digital literacy & $.468^{\star}$ & -.169 & .227 & .026 \\
SKC general literacy & $.466^{*}$ & .086 & -.203 & -.319 \\
Professional skills & $.411^{*}$ & .087 & .226 & -.208 \\
AKC skills & $.407^{*}$ & -.140 & .349 & .102 \\
Professionalism development & $.402^{*}$ & -.178 & .222 & .375 \\
AKC general literacy & $.390^{*}$ & -.119 & .307 & -.080 \\
Academic topics & .144 & $.590^{\star}$ & .007 & .123 \\
Values & .228 & $.531^{*}$ & .484 & -.285 \\
Key skills & .323 & .458 & $.479^{*}$ & -.277 \\
AKC capacity for change & .358 & -.203 & $.473^{*}$ & .317 \\
Advancement for a job & .336 & -.054 & $.397^{*}$ & -.028 \\
Career advancement & .282 & -.037 & $.371^{*}$ & .237 \\
Negative beliefs & -.177 & .259 & -.344 & $.375^{*}$ \\
\hline
\end{tabular}

* largest absolute correlation between each variable and any discriminant function

The mutual distance on a linear composite that maximally differentiates groups is almost four and a half standard deviations for the first function, three and a half standard deviations for the second, two and a half for the third and one and a half for the fourth (see Table 5). The classification efficiency of respondents based on isolated discriminant function is $91.4 \%$.

Table 5. Functions at Group Centroids

\begin{tabular}{cccccc}
\hline Ward Method & \multicolumn{5}{c}{ Function } \\
& 1 & 2 & 3 & 4 & category names \\
\hline 1 & -1.051 & -.664 & 1.581 & .490 & Pragmatic Careerism \\
2 & -2.940 & -.075 & -.375 & -.769 & Low Careerism \\
3 & -.795 & 1.428 & -.939 & .750 & Self-confident Careerism \\
4 & 1.512 & .513 & .245 & -.297 & High Careerism \\
5 & .912 & -2.082 & -1.094 & .204 & Narrow Professionalism \\
\hline
\end{tabular}

The largest group of students makes up 39\% of our sample and is a category of students with high focus on additional education with a high (self)assessment of competencies (group 4). Most variables came first in terms of expression, and 
three came second (see Table 6). It is the group where the first function is most pronounced and then the second. We named it High Careerism.

The group of opposite characteristics makes up 14.5\% of the sample of students and represents the category of low focus on additional education with low (self)competence assessment (group 2). Most variables are in the last place in terms of expression, three next-to-last and two mean values. In this group, the first function is the least pronounced and the fourth function is the highest. We named it Low Careerism.

The same size has a group of students with a high focus on professionalism and relatively high (self)assessment of competencies (group 5). Although most variables are second in terms of expression, among the first are Professionalism Development and self-assessment of Digital Literacy. This category is characterized by the lowest values of desire for additional education, with the exception of Professional Skills, which is in second place. In this group, the second and third functions are the least pronounced and the first function relatively high. We named it Narrow Professionalism.

The first group includes $16.5 \%$ of students from the sample and represents a category of significant focus on additional education with a relatively low selfassessment and a medium pronounced assessment of competence. Unlike groups 4 and 5, there is a lower emphasis on professionalism, they have the lowest Negative Beliefs and self-assessment of Digital Literacy, and there is a high assessment of employers' requirement for Capacity for Change and then Skills in employees. In this group, the third function is most pronounced, and the fourth function is relatively pronounced. The big gap between strong beliefs about additional education and poor self-assessment of competencies, as well as between selfassessment and competency assessment, combined with an emphasis on Key Skills training, is indicating a group that is aware of its shortcomings but not sufficiently motivated to work on professional development, but rather to build his career in easier way. So we named the group Pragmatic Careerism. 
Table 6. Means of research variables in the groups Pragmatic careerism, Low careerism, Self-confident careerism, High careerism and Narrow professionalism.

\begin{tabular}{lcccccc}
\hline \multirow{2}{*}{ research variables } & 1 & 2 & 3 & 4 & 5 & Total \\
& $\mathrm{N}=31$ & $\mathrm{~N}=27$ & $\mathrm{~N}=29$ & $\mathrm{~N}=73$ & $\mathrm{~N}=27$ & $\mathrm{~N}=187$ \\
\hline Advancement for a job & 4.72 & 3.70 & 3.97 & 4.93 & 4.49 & 4.51 \\
Professionalism & 5.27 & 4.41 & 4.91 & 5.38 & 5.44 & 5.16 \\
development & 1.56 & 2.19 & 2.91 & 1.57 & 1.65 & 1.88 \\
Negative beliefs & 4.90 & 3.68 & 4.22 & 4.90 & 4.55 & 4.57 \\
Career advancement & 4.31 & 3.68 & 4.20 & 5.01 & 2.95 & 4.28 \\
Values & 4.32 & 3.60 & 4.14 & 5.05 & 3.38 & 4.34 \\
Key skills & 2.67 & 2.57 & 4.02 & 3.68 & 2.02 & 3.16 \\
Academic topics & 4.45 & 3.77 & 4.20 & 5.22 & 4.56 & 4.63 \\
Professional skills & 4.00 & 3.50 & 4.50 & 4.98 & 4.95 & 4.52 \\
SKC skills & 3.73 & 3.70 & 4.25 & 5.02 & 4.75 & 4.46 \\
SKC general literacy & 3.17 & 3.20 & 4.17 & 4.80 & 4.98 & 4.23 \\
SKC digital literacy & 4.13 & 3.54 & 4.71 & 5.12 & 4.90 & 4.63 \\
SKC capacity for change & 5.28 & 4.24 & 4.63 & 5.49 & 5.30 & 5.11 \\
AKC skills & 4.76 & 3.85 & 4.10 & 5.11 & 4.85 & 4.68 \\
AKC general literacy & 4.60 & 3.49 & 3.99 & 5.11 & 5.01 & 4.60 \\
AKC digital literacy & 5.46 & 4.07 & 4.52 & 5.33 & 5.22 & 5.03 \\
AKC capacity for change & & & & & & \\
\hline
\end{tabular}

The third group includes $15.5 \%$ of students and represents the category of low focus on additional education with prominent Negative Beliefs, with medium self-assessment and relatively low assessment of competencies. What is interesting about this group is the difference between self-assessments and assessments is in favour of self-assessments of competencies. Although selfassessments are medium in comparison to other groups, and assessments are relatively low, this indicates the assuredness and self-overestimation of students in a given group. The desires for additional education are medium and uniform and therefore a high value for Academic Topics is obtained. This can be explained by the responses within the medium tendency, which further confirms selfabsorption in the students of this group. The finding of relatively low beliefs about additional education contributes to this. Therefore, we called this group Self-confident Careerism.

\section{Discussion}

The results of our research show that students differ in self-assessment of competencies, assessment of competencies sought by employers, beliefs 
about additional education and choices of additional education. We separated five groups of students based on the differences. The first important finding is that $53.5 \%$ of our sample is highly focused on professionalism and learning (High Careerism and Narrow Professionalism groups). If we add a group of Pragmatic Careers, we get $70 \%$ of the sample that is clearly committed to developing professionalism and enhancing competencies through learning and education.

The importance that these student groups attach to competencies and additional education is noticeable. All research variables are highly expressed in the High Careerism group, which makes up 39\% of the sample, and in the other two groups they move towards moderately pronounced measures with different emphasis on individual variables. Thus, among Narrow Professionalism the most pronounced is investment in the development of professionalism and professional skills, while for Pragmatic careerists there is an awareness of the underdevelopment of competences in relation to the needs in the labour market and, consequently, the need to invest in the development of key competences.

Such findings indicate the importance of investing in key competences for the development of professionalism, which is in line with the results of the REFLEX (Research into Employment and Professional FLEXibility) project, conducted in 16 countries of the European Union, that key competences only make sense within the area of professional expertise (Allen \& van der Velden, 2007). An important conclusion of the REFLEX project is that professional expertise plays a dominant role as a determinant of success in the job market, and that after graduation almost all of them continue to train either to update their current job knowledge or to strengthen their careers (Allen \& van der Velden, 2007).

High Negative beliefs about additional education were present in two groups of students we called Low Careerism (14.5\%) and Self-confident Careerism (15.5\%). In other words, $30 \%$ of students tend to negatively view additional education which is contrary to common sense expectations. It would be interesting to investigate the motivation of a given group of students to study, which motives, apart from education and learning, participate in the need to study. Personality traits should be included in this research, because we could expect to find persons who are poorly integrated, do not believe in success, have low self-efficacy, and the like.

What can be noticed in our sample is that a group of students labelled SelfConfident Careerism are turning to Academic Topics when choosing additional education. Another group that attaches importance to the choice of Academic Topics is High Careerism. In the first group, this can be interpreted as tendency to run away from reality and seek support in theoretical thinking. However, the 
importance of Academic Topics for High Careerism indicates that they are chosen for the purpose of raising personal literacy levels, and that personal literacy is seen as significant for overall career development. Research by other authors suggests that liberal education is useful in periods of change, because it offers the person to expand the scope of his or her experience through increasing the horizon of knowledge that is relevant to personal identity (Hinchliffe, 2013). The REFLEX project indicated that flexible graduates positively evaluate programs that emphasize theories and paradigms (Allen \& van der Velden, 2007).

Universities play a significant role in preparing the transition from student identity to workplace identity. Just as it is important to distinguish between students at the beginning of their studies and students in their final years of study, so it is important to tailor the approaches to different groups of students, given the strength of careerism, as demonstrated by our research. Particularly relevant is the work on empowering thinking from a broader perspective, as well as reflecting on learning and development processes (Hinchliffe, 2013). This is achieved, among other things, by raising students' awareness of what is currently being done in class. The simplest approach is to emphasize that through certain activities one wants to improve certain skills, such as critical thinking, shifting perspectives on the problem, identifying conflict situations during teamwork, and the like. Students need to be convinced that what is happening in teaching is similar to workplace situations and is a good preparation for a future role (Campana \& Peterson, 2013). But students should equally be encouraged to gain relevant experience beyond higher education and to develop a good social network.

Thus, our research shows that a high percentage (70\%) of students are directed toward improvement to increase personal professionalism; that any education is important for professional development, even one that is not directly related to the requirements of the profession (e.g. liberal education), that students work to increase their personal literacy (e.g. choice of academic topics), and that students are guided by assessments of competencies which are valued by employers when selecting topics for additional training. 


\section{References}

Allen, J. \& van der Velden, R. (Eds.). (2007). The Flexible Professional in the Knowledge Society: General Results of the REFLEX Project. Maastricht University: Research Centre for Education and the Labour Market.

Babić, L., \& Kordić, B. (2014). Razvoj veština za samostalno upravljanje karijerom: Učenje upoznavanja sebe i donošenja odluke o karijeri. Beograd: Fakultet bezbednosti.

Banerji, S. (2007). Report: Employers say college graduates lack essential skills to succeed in today's global economy. Diverse: Issues in Higher Education, 23(26), 18.

Barnes, A., Bassot, B., \& Chant, A. (2011). An introduction to career learning and development. London \& New York: Routlege.

Burrus, J., Jackson, R., Xi, N. \& Steinberg, J. (2013). Identifying the most important 21st century workforce competencies: An analysis of the occupational information network (O*NET). In J. Carlson (Ed.), ETS Research Report Series. Princeton, NJ: Educational Testing Services.

Campana, K. L., \& Peterson, J. J. (2013). Do bosses give extra credit? Using the classroom to model real-world work experiences. College Teaching, 61(2), 60-66.

Cappellen, T., \& Janssens, M. (2008). Global managers' career competencies. Career Development International, 14(6), 514-537.

Casner-Lotto, J., \& Barrington, L. (2006). Are they really ready to work? Employers' perspectives on the basic knowledge and applied skills of new entrants to the 21st century U.S. workforce. New York, NY: The Conference Board.

Creed, P. A., Prideaux, L., \& Patton, W. (2005). Antecedents and consequences of career decisional states in adolescence. Journal of Vocational Behaviour, 67, 397-412.

Finegold, D., \& Notabartolo, A. S. (2008). 21st century competencies and their impact: An interdisciplinary literature review. Received from: http://www.hewlett.org/wpcontent/uploads/2016/11/21st_Century_Competencies_Impact.pdf

Griffin, P., \& Care, E. (Eds.). (2015). Assessment and teaching of 21st century skills: Methods and approach. Dordrecht: Springer.

Gallup, Inc. (2013). 21st century skills and the workplace: A 2013 Microsoft Partners in Learning and Pearson Foundation study. Washington, DC: Gallup, Inc. Preuzeto sa http://www.gallup.com/

García-Aracil, A., \& Van der Velden, R. (2008). Competencies for Young European higher education graduates: Labour market mismatches and their payoffs. Higher Education, 55, 219-239.

Hall, D. T., \& Moss, J. E. (1998). The new protean career contract: helping organizations and employees adapt. Organizational Dynamics, 26(3), 22-37. 
Hartog, J. (2001). On human capital and individual capabilities. Review of Income and Wealth, 47(4), 515-540.

Hinchliffe, G. (2013). Workplace Identity, Transition and the Role of Learning. U Gibbs, P. (Ed.). Learning, work and practice: New understandings (pp. 51-66). Dordrecht: Springer.

Hughes, D., Bosley, S., Bowes, L., \& Bysshe, S. (2002). The economic benefits and guidance [Research report]. Derby, UK: Centre for Guidance Studies, University of Derby.

Mortimer, J. T., \& Zimmer-Gembeck, M. (2007). Adolescent paid work and career development. U V. B. Skorikov \& W. Patton (Eds.), Career development in childhood and adolescence (pp. 255-275). Rotterdam: Sense Publishers.

Olson, J. S. (2014). Transitions from Formal Education to the Workplace. New directions for adult and continuing education, 143(3), 73-82.

Patton, W., Creed, P., \& Muller, J. (2002). Career maturity and well-being as determinants of occupational status of recent school leavers: A report of an Australian study. Journal of Adolescent Research, 17(4), 425-435.

Porfeli, E. J. (2007). Work values system development during adolescence. Journal of Vocational Behavior, 70, 42-60.

Rychen D. S., \& Salganik, L. H. (Eds.). (2003). Key Competencies for a Successful Life and a Well-Functioning Society. Göttingen, Germany: Hogrefe \& Huber.

Staff, J., Messersmith, E. E., \& Schulenberg, J. E. (2009). Adolescents and the world of work. In R. M. Lerner \& L. Steinberg (Eds.), Handbook of adolescent psychology (pp. 270-313). NY: John Wiley \& Sons.

Teijeiro, M., Rungo, P., \& Freire, M. (2013). Graduate competencies and employability: The impact of matching firms' needs and personal attainments. Economics of Education Review, 34, 286-295.

Zimmer-Gembeck, M. J., \& Mortimer, J. T. (2006). Adolescent work, vocational development, and education. Review of Educational Research, 76, 537-566. 


\title{
ГРУПИРАЊЕ НА СТУДЕНТИТЕ СПОРЕД МОДАЛИТЕТИТЕ НА (САМО) ПРОЦЕНКА НА КОМПЕТЕНЦИИТЕ И ПЛАНИРАЊЕ НА ОБРАЗОВАНИЕТО
}

\author{
Лепа Бабиќ
}

\section{Кратка содржина}

Студентите на крајот на својата студија се наоѓаат на преминот од улогата на студентот со акцент на учење во улога на вработен со акцент на работните перформанси. Беше спроведено истражување на примерок од студенти од Скопје ( $=189)$ со цел да се утврдат типични студентски групи според модалитетите на (само)проценка на клучните компетенции и планирање на образованието. Инструментите што беа користени: прашалник на клучните компетенции стекнати за време на студирањето (Cronbach's Alpha = 0.933), прашалник на клучни компетенции потребни за вработување (0.938), прашалник на уверувањата за дополнителна едукација (0.861), прашалник за избор на дополнителни едукации (0.919). Врз основа на дискриминаторска и кластерска анализа, пет групи се разликуваат (коефициентот на канонска корелација е .85, .73, $.66, .45)$. Разликите помеѓy пет групи се во интензитет, но и во квалитет (Box’s M test $F=1.479$, Sig. < .001). Им дадовме следни имиња на групи студенти: Висок кариеризам (39\% од примерокот), Низок кариеризам (14,5\%), Тесен професионализам (14,5\%), Прагматичен кариеризам (16,5\%) и Самоуверен кариеризам (15,5\%). Така, $70 \%$ од студентите позитивно ја гледаат улогата на дополнително образование во подигнување на компетенциите, што укажува на јасна посветеност за работа кон развој на професионализам и подобрување на компетенциите преку учење и образование. Од друга страна, 30\% од студентите покажуваат тенденција негативно да следат дополнителни едукации во контекст на развој на компетенции. Идните истражувања треба да испитаат кои мотиви се вклучени во потребата за студирање и дали постојат врски помеѓу одредени црти на личноста и образовното планирање.

Клучни зборови: клучни комӣейенции, gойолнииеелно образование, иррофесионализам, кариера 